to serve his purpose of Zulu supremacy and his own personal dominance. Obviously Zulu history is not without its lessons for to-day, when it thus demonstrates the political capacities and social adaptability of the African along lines congenial to his traditions.

This and like reflections must occur to any reader interested in the African, who takes Miss Krige's book in hand. Such broader implications of the theme lie beyond her scope; but she sketches the history of the Zulu people adequately to show its bearing on the development of Zulu society. Much of the old military organization, such as the regiments, survives, although it has lost its military purpose and meaning; and checks and counter-checks devised to consolidate Shaka's power, as for example in overriding the witchfinder, are still operative.

\title{
The Nile
}

The Nile:

the Life-Story of a River; from the Source to Egypt. By Emil Ludwig. Translated by Mary H. Lindsay. Pp. $352+34$ plates. (London: George Allen and Unwin, Ltd., 1936.) 16s. net.

IN this book a famous biographer has attempted to give a description of the course of the Nile from its sources to the sea as if it were the lifehistory of a person. In it the reader with no firsthand knowledge will find much interesting information about the topography, vegetation, human and animal life, and history of the Nile basin, and may think that he is reading an authoritative work by one who has seriously studied the river and travelled extensively in its basin. If, however, he is sufficiently interested to pursue the subject further and refers to standard works, his confidence in the author will be badly shaken by the many mistakes which he will discover. The book is written in flowery language, and the reader will become very weary of the personality device and its meaningless symbolism before he comes to the end.

The first portion of the book is concerned with the great Lakes Victoria and Albert and the surrounding country in which the White Nile has its sources. Some of the information produced about the region is a little surprising, as for example the natural bridge at Nimule, "such as hardly another river on earth possesses in this form, consisting of rank water plants, so strong that it bears the elephant from one bank to the other, and so powerfully rooted that when floods have destroyed it, it closes up again of itself". Nobody else has ever reported this bridge, and as an elephant weighs five tons or more, the rank water plants must have been considerable trees. Some of the remarks about evaporation are equally strange, for the author says: "As Lake Victoria is not three hundred feet deep, so that more water evaporates than is received, this constant diminution, as we shall see later, presents the Nile engineers with a very grave problem." This is an example of the lack of knowledge of the elements of natural science displayed in the book and of the inaccuracies which are of frequent occurrence. Lake Victoria has not progressively diminished in volume in the forty years over which records extend, though, like other large lakes, it has fluctuated with the variations of the rainfall.

The author continues his description of the White Nile and then describes the Blue Nile and the Atbara, with some account of the history of Abyssinia, and the Main Nile as far as Aswan, the description of Egypt being left for a second volume. Towards the end of the book he has a few paragraphs on hydrology in which he gives some figures about the volumes of water flowing in the various tributaries. As many of these figures are badly wrong, it would have been better to have omitted them.

The remarkable feature about the book is the number of errors it contains. Some, like the picture of hippopotami entitled "rhinoceros" and the statements that the hippopotamus has been seen starving to death on phantom islands of grass, and that the Atbara rises in Lake Tana, will be readily detected ; others, like the statistical errors, of which there are so many, will escape the notice of the general reader and be assimilated and perpetuated, for a false statement once started can never be overtaken. The most reliable feature of the book is the maps, which are taken from another work.

It is a misfortune that a book which is written by a well-known author should be so unreliable; but in a serious description of natural phenomena there is no excuse for gross inaccuracies, and the author owes it to his own reputation as well as to his readers to make no mistakes in his presentation of facts. Perhaps the lesson may be drawn that literary ability will not make up for lack of knowledge of the subject, and we recommend this consideration to the author before he produces the second volume of the work.

H. E. Hurst. 